\title{
Calibration of DRAINMOD for prediction of water table depths and drain discharges under waterlogged Vertisols of Maharashtra, India
}

\begin{abstract}
Shrimant Rathod*
NARP, Agricultural Research Station, Kasabe Digraj, Sangli- 416305 (Maharashtra), India Sudhir Dahiwalkar

Dr. Annasaheb Shinde College of Agricultural Engineering and Technology, Mahatma Phule Krishi Vidyapeeth, Rahuri, Ahmednagar- 413722 (Maharashtra), India

Sunil Gorantiwar

Dr. Annasaheb Shinde College of Agricultural Engineering and Technology, Mahatma Phule Krishi Vidyapeeth, Rahuri, Ahmednagar- 413722 (Maharashtra), India

Mukund Shinde

Dr. Annasaheb Shinde College of Agricultural Engineering and Technology, Mahatma Phule Krishi Vidyapeeth, Rahuri, Ahmednagar- 413722 (Maharashtra), India

*Corresponding author. E-mail: sdrathod2004@gmail.com

\section{Abstract}

An estimation of optimal design parameters of subsurface drainage system through monitoring of water table depths and drain discharges are expensive in terms of time and money. The simulation modeling is an effective tool for estimation of drainage design parameters at less cost and short time. In view to this, calibration of DRAINMOD model for prediction of water table depths and drain discharges were conducted by installing subsurface drainage system with $40 \mathrm{~m}$ drain spacing and $1.0 \mathrm{~m}$ drain depth at Agricultural Research Station, Kasbe Digraj, Dist. Sangli (Maharashtra) during 2012-13 to 2013-14. The field data on water table depth and drain discharge were used for calibration of DRAINMOD model. The input data files on climatic, soil, crop and drainage design system parameters were attached to DRAINMOD model and calibrated successfully. It is found that both observed and simulated water table depths and drain discharges showed a fluctuating trend and predicted both water table depths and drain discharges closely with the observed values during frequent rainy days and following the rainy days. The DRAINMOD model reliably predicted water table depths with a goodness of fit $\left(R^{2}=0.97\right)$, MAE $(12.23 \mathrm{~cm})$, RMSE $(15.49 \mathrm{~cm})$ and CRM (0.05); drain discharges with $\mathrm{R}^{2}$ of 0.93 , MAE of $0.095 \mathrm{~mm}$ day $^{-1}$, RMSE of $0.1876 \mathrm{~mm}^{\text {day }}{ }^{-1}$ and CRM of 0.04 . Thus, the calibrated DRAINMOD model can be used to simulate the water table depths and drain discharges in semi-arid climatic conditions of Maharashtra and in turn to estimate and evaluate drain spacing and depth.
\end{abstract}

Keywords: Drain discharge, DRAINMOD, Subsurface drainage system, Vertisols and Water table depth

\section{INTRODUCTION}

In India, 35.5\% of India's Vertisols area (72.9Mha) is in Maharashtra alone (Murthy et al.,1982). These soils are more prone to drainage problems under irrigated conditions. In the absence of appropriate and adequate drainage, irrigation proved a boon initially but might turn to be a curse in some pockets of the commands of irrigation schemes including canal and lift irrigation schemes. Coupled with poor natural drainage and poor quality ground water resource at many places of Maharashtra resulted in development of salinity, sodicity and waterlogging problems in Sangli, Kolhapur, Satara, Solapur, Pune, Ahmednagar, Nashik, Jalgaon, Dhule and Nandurbar Dis- tricts of Western Maharashtra; Wardha, Akola and Amravati Districts of Vidharbha region; Aurangabad, Parbhani and Nanded Districts of Marathwada region; and many areas are turned barren within 10 to 15 years after introduction of irrigation. Subsurface drainage system (SSDS) is a proven technology to combat the twin problems of salinization and waterlogging (Rathod, 2017). However, the effectiveness of SSDS depends upon the optimal combination of drain spacing and depth. Malota and Senzanje (2015) reported that determining optimal SSDS design parameters through monitoring of mid-span water table depths (WTDs) and drain discharges at various combinations of drain depths and drain spacings are expensive, both in terms of time and money. As an 
alternative, scientists and engineers have developed numerical models to predict the behaviour of phenomena before it happens in the real world. Therefore, the purpose of this investigation was to predict the mid-span WTDs and drain discharges through simulation modeling and compare their results against observed data.In this study, DRAINMOD model (Skaggs 1978 and 1980) was chosen among three most reliably used models for simulation of WTDs and drain discharges under SSDS viz., DRAINMOD, SaltMOD and WaSim. DRAINMOD is one of the most widely applied model in SSDS design and widely tested under various climatic, crop and soil conditions. Haan and Skaggs (2003) reported that DRAINMOD can estimate the drain discharge and WTDs under various field conditions as compare to field monitoring. This further facilitates to take proper decisions in case of complicated situations when collection of field information were both costly and laborious. The results of the DRAINMOD model performance in South Africa (Malota and Senzanje, 2015 and Sema Kale, 2011), Egypt (Neveen et al., 2013), Israel (Sanai and Jain, 2006), lowa (Singh et al., 2006), Iran (Hassanpour et al., 2011, Samipour et al., 2010 and Ebrahimian et al., 2010) and Iraq (Hamdi et al., 2006), confirmed that DRAINMOD can reliably imitate SSDS for various soils and weather situations. Further, it is also found from reviews that the DRAINMOD model is widely used model for design of SSDS under shallow water table conditions as reported by Prasher et al. (1996), Borin et al. (2000), Singh et al. (2006), Hamdi et al. (2006), Wang et al. (2006), Hassanpour et al. (2011), Skaggs et al. (2012), Neveen et al. (2013) and Mohammadighavam and Klove (2016). However, shallow WT conditions may arise in irrigated Vertisols due to excess irrigation through surface irrigation methods and heavy rainfalls. Gupta et al. (1993), Yang (2008), Ebrahimian et al. (2010), Samipour et al. (2010) and Malota and Senzanje (2015) reported the prediction of WTDs and drain discharges successfully through DRAINMOD in irrigated conditions. However, there was very limited research on suitability of DRAINMOD under irrigated arid and semiarid conditions particularly in India. In view to above, the field testing, calibration and evaluation of DRAINMOD model under irrigated and semiarid conditions of India with the objective to predict the mid-span WTDs and drain discharges through simulation modeling and compare their results against observed data. This will be helpful for further estimation of design parameters of subsurface drainage system.

\section{MATERIALS AND METHODS}

Experimental site: In order to fulfill the objective of the study, the field experiment was carried out on farmer's field under irrigated sugarcane at Vil- lage Mouje Digraj of Sangli district (Maharashtra), India during 2012-13 and 2013-14. The experimental size of $216 \mathrm{~m} \times 54 \mathrm{~m}$ was surveyed with Dumpy Level at $18 \mathrm{~m} \times 18 \mathrm{~m}$ grid for the contour map and layout of SSDS. The parallel SSDS (gridiron) was installed as per layout by using 80 $\mathrm{mm}$ diameter perforated corrugated PVC drainage pipes with geo-textile synthetic filter as lateral drains and non perforated corrugated PVC pipe of $80 \mathrm{~mm}$ diameter as a collector drain. These lateral drains were connected to the collector drain at a grade of $0.2 \%$. The collector drain was laid on a uniform grade of $0.2 \%$. The soil was clayey in texture as clay content was $59.73 \%$. The $\mathrm{pH}$ and electrical conductivity of soil were 7.65 to 7.93 and 0.49 to $1.15 \mathrm{dS} \mathrm{m}^{-1}$ respectively. The quality of irrigation was $\mathrm{C}_{1} \mathrm{~S}_{1}$ (low salinity and sodium hazards) in Kharif and $\mathrm{C}_{2} \mathrm{~S}_{1}$ (medium salinity and low sodicity hazards) in both rabi and summer season. The irrigation interval was generally 25-30 days due to rotational supply system of co-operative lift irrigated scheme. Hence, the excess application of irrigation water per irrigation is the common practice and created waterlogging at the experimental site. The water table depth was within $0.6 \mathrm{~m}$ in rainy season and 0.9 to $1.5 \mathrm{~m}$ in winter and summer season before installation of SSDS.

Description of the DRAINMOD 6.1 model: In 1980, Dr. Wayne Skaggs developed the one dimensional computer simulation model i.e., DRAINMOD at the Department of Biological and Agricultural Engineering, North Carolina State University. It focuses on drainage in soils and estimates the impact of drainage on WTDs, soil water regime and yield of crop (Skaggs, 1985). The latest version, DRAINMOD 6.1 provides a graphical user interface that facilitates easy preparation of input data sets, running simulations as well as displaying model outputs.

DRAINMOD is a deterministic, hydrologic model developed for the purpose of simulating a soilregime of drainage landscapes (Figure 1). This model uses functional algorithms to approximate the hydrological components in soils with shallow water tables (Skaggs, 1978). Soil, weather and crop information are the important inputs to the model. Whereas, daily WTD, drain discharge, infiltration and runoff are its outputs. These outputs are primarily estimated from the water balance of a unit soil section located mid-way between two drains as given in DRAINMOD reference report (Skaggs, 1985)

Daily WTDs at different drain spacing were computed from the steady state Hooghoudt's equation (Hooghoudt, 1940)

$$
\mathrm{q}=\frac{4 \mathrm{~K}_{\text {sat }} \mathrm{h}\left(\mathrm{h}+2 \mathrm{~d}_{\mathrm{e}}\right)}{\mathrm{L}^{2}}
$$

Where, $q$ is drainage discharge $\left(\mathrm{mm} \mathrm{day}^{-1}\right), \mathrm{L}$ is drain spacing $(m), K_{\text {sat }}$ is saturated soil hydraulic conductivities $\left(m\right.$ day $^{-1}$ ) for soil layers up to $d_{e}, d_{e}$ 
is Hooghoudt's equivalent depth $(\mathrm{m})$ and $\mathrm{h}$ is hydraulic head mid-way between two drains (m) (see Figure 2)

DRAINMOD model inputs: The following inputs were required for calibration of DRAINMOD 6.1 model,

Climatic parameters: DRAINMOD model works on water balance and daily crop evapotranspiration (ETc) is one of the important input parameter of this model. It is, therefore, the climatic data was necessary for the computation of ETo. The data was collected for the period from $1^{\text {st }}$ August 2012 to $31^{\text {st }}$ December 2013 from weather station observatory, Agricultural Research Station, Kasbe Digraj, Tal. Miraj, Dist. Sangli. The climatological data viz., daily precipitation, daily maximum temperature (Tmax), daily minimum temperature (Tmin), pan evaporation (Ep), daily relative maximum humidity (RHmax) and daily relative minimum humidity (RHmin), wind speed and sunshine hours were used for calculation of daily reference evapotranspiration (ETo) with Penman-Monteith method by using 'Phule Jal' Software developed at Department of Irrigation and Drainage Engineering, Dr. Annasaheb Shinde College of Agricultural Engineering and Technology, MPKV, Rahuri. Further, ETc values were calculated by multiplying ETo with Kc values of sugarcane crop. These crop growth stage wise Kc values were taken from FAO guidelines on crop coefficients for sugarcane (FAO, 2015). Further, daily Kc values were determined by plotting these $\mathrm{Kc}$ values against crop growth stages on graph paper.

In this model, the rainfall input file needs addition of depth of irrigation $\left(\mathrm{mm} \mathrm{day}^{-1}\right)$ throughout the study period for accounting soil system recharge through irrigation. Hence, irrigation depth in $\mathrm{mm}$ day $^{-1}$ were measured at the experimental site by using relationship between discharge rate of the irrigation pipe (Ips), time of irrigation and area irrigated.

\section{Soil parameters}

Saturated hydraulic conductivity of soil: The layer wise saturated hydraulic conductivity soil $\left(\mathrm{K}_{\mathrm{sat}}\right)$ values are the most important input parameter of the model. Hence, it was necessary to the study the heterogeneity of soil for determination of saturated hydraulic conductivity of soil $\left(\mathrm{K}_{\text {sat }}\right)$ in $\mathrm{m}$ day $^{-1}$. Accordingly, layer wise soil heterogeneity were studied by digging hole with $24 \mathrm{~cm}$ outer diameter post hole auger up to $370 \mathrm{~cm}$ depth and found heterogeneity at $0-30 \mathrm{~cm}, 30-130 \mathrm{~cm}, 130-$ $250 \mathrm{~cm}, 250-300 \mathrm{~cm}$ and $300-370 \mathrm{~cm}$. It was, therefore, in-situ $\mathrm{K}_{\text {sat }}$ values at four various places in the field at $0-130 \mathrm{~cm}, 130-250 \mathrm{~cm}, 250-300 \mathrm{~cm}$ and $300-370 \mathrm{~cm}$ soil depth were determined by Hooghoudt's single auger hole method. The $\mathrm{K}_{\text {sat }}$ values of water transmitting layer (depth of drains + Hooghoudt's equivalent depth, de) contributed flow to drains were calculated for different soil layers. The 'de' was calculated by Moody's empiri- cal equation for each DS and DD combination as $\mathrm{d} / \mathrm{L}>0.3$.

$\frac{L}{d e}=8\{\ln (L / r)-1.15\} / \pi$

Where, $L$ is drain spacing $(m), r$ is radius of drain pipe (m)

Soil moisture capacities: Moisture capacities at various pressure heads w.e.f. from 0 to $15000 \mathrm{~cm}$ were determined by pressure plate apparatus and soil moisture content were calculated by oven dry method. These moisture capacities at various pressure heads were required for model calibration.

WTDs versus Green-Ampt infiltration parameters: The methods described in DRAINMOD reference report were used to determine the WTD versus Green-Ampt Infiltration parameters. Green and Ampt (1911) has developed following equation for finding out the Green Ampt Infiltration parameters as belows

$$
\mathrm{f}=\frac{\mathrm{A}}{\mathrm{F}}+\mathrm{B} \ldots(3)
$$

Where, $\mathrm{f}$ is Infiltration rate $\left(\mathrm{cm} \mathrm{hr}^{-1}\right), \mathrm{F}$ is accumulated infiltration $(\mathrm{cm}), A$ and $B$ are Green-Ampt infiltration parameters, $B$ is vertical saturated hydraulic conductivity $\left(\mathrm{cm} \mathrm{hr}^{-1}\right)$. The value of $B$ at upper layer was taken as $\mathrm{K}_{\text {sat }}$ of upper layer and at bottom layers were slightly less than $\mathrm{K}_{\text {sat }}$ of bottom soil layers. The values of $f$ and $F$ were determined from double ring infiltrometer test and slope of $f$ versus $1 / \mathrm{F}$ was taken as value of $A\left(\mathrm{~cm}^{2} \mathrm{hr}^{-1}\right)$. Further calculations of $A$ and $B$ at different WTD were determined as per the procedures explained in DRAINMOD reference report.

WTDs versus downward flux and upward flux: The slope of WTD $(\mathrm{cm})$ versus downward flux $(\mathrm{cm})$ is nothing but the drainable porosity of soil. Accordingly, downward fluxes at particular WTD were calculated by multiplying the drainable porosity of soil to the particular WTD. Whereas, WTD versus upward flux was calculated by using the Anat's Equation (Skaggs, (1985). DRAINMOD: Reference Report, 5-19).

Crop data: The crop input data requires relationship between effective rooting depth and time. The change in the effective root depth with time can be estimated by using crop growth stage coefficients (crop coefficients, Kc). These crop growth stage wise $\mathrm{Kc}$ values were taken from $\mathrm{FAO}$ guidelines on crop coefficients for sugarcane (FAO, 2015). Further, daily and monthly $\mathrm{Kc}$ values were determined by plotting Kc values versus crop growth stage period on graph paper. The monthly variation of effective root depth were determined by using the following equation suggested in DRAINMOD reference report,

$$
\mathrm{R}_{\mathrm{d}}=\mathrm{a} \mathrm{Kc}+\mathrm{b} \quad \ldots \text { (4) }
$$

Where, $R_{d}$ is effective rooting depth $(\mathrm{cm})$ and taken as $60 \mathrm{~cm}$ when Kc was highest (1.375) and 3 
$\mathrm{cm}$ when Kc was lowest (0.4), a and b are coefficients which were determined by solving Eqn.4 simultaneously.

Drainage design system parameters: The various inputs on drainage designs viz., depth of drain from soil surface, distance between two drains, effective radius of drains, depth of impermeable layer from soil surface, equivalent depth from drain to permeable layer, drainage coefficient, initial depth to water table, maximum surface storage, Kirkham's depth for flow to drains etc., required for simulation of daily WTDs, were obtained from installed SSDS.

Field measurement of WTDs and drain discharges: The observed WTDs and drain discharges were required for performance evaluation of DRAINMOD. The simulated WTDs and drain discharges were statistically compared with the observed WTDs and drain discharges. For measurement of WTDs and drain discharges, five piezometers were installed across the subsurface drain. One piezometer $(80 \mathrm{~mm}$ internal diameter PVC pipe with perforations) was installed on lateral drain and remaining at a distance of half and quarter of drain spacing at both sides of lateral drain by using a $120 \mathrm{~mm}$ outside diameter auger to a depth of $1.7 \mathrm{~m}$ from the soil surface for periodically measurement of WTDs after rainfall or irrigation. The whole perforated section of pipe was backfilled with coarse sand. WTDs at each piezometer were measured by gradually lowering the locally made measuring meter with float in the piezometers until metered hollow pipe floats on water. On the other hand, drainage outflows $(Q)$ in $\mathrm{m}^{3}$ day $^{-1}$ were manually measured at drainage outlet point, using a bucket and a stop watch.

Calibration, evaluation and statistical analysis of DRAINMOD: The three months daily WTD and corresponding drain discharges from DS of $40 \mathrm{~m}$ and DD of $1.0 \mathrm{~m}$ data were used for calibration. Effective root zone depth for sugarcane was fixed at $60 \mathrm{~cm}$ from the soil surface (Malota and Senzanje, 2015, and Savva and Frenken, 2001). The trial-and-error basis were used for calibration of DRAINMOD (Dayyani et al., 2010), by adjusting any or a set of input parameters presented in Table 1, until an optimal agreement between observed and simulated data sets were achieved.

Time series of WTDs and drain discharges were simulated using the DRAINMOD model after every alteration of an input parameter or set of pa- rameters. Simulated WTDs and drain discharges were then compared to field recorded WTDs and drain discharges. Initially, the agreement between the two data sets was assessed by visual judgments from WTD and drain discharge hydrographs. Later on four statistical parameters were used to characterize the DRAINMOD model performance, namely, Pearson's product-moment correlation $\left(\mathrm{R}^{2}\right)$ (Eqn.5), RMSE (Eqn.6), MAE (Eqn.7), and coefficient of residual mass (CRM) (Eqn.8) to find out the quality and reliability of the predictions when compared to observed values.

$$
\begin{aligned}
& \mathrm{R}^{2}=\frac{\left(\sum_{\mathrm{i}=1}^{\mathrm{n}}(\mathrm{Oi}-\overline{\mathrm{O}})(\mathrm{Pi}-\overline{\mathrm{P}})\right)^{2}}{\sum_{\mathrm{i}=1}^{\mathrm{n}}(\mathrm{Oi}-\overline{\mathrm{O}})^{2} \sum_{\mathrm{i}}^{\mathrm{n}}(\mathrm{Pi}-\overline{\mathrm{P}})^{2}} \\
& \text { RMSE }=\sqrt{\frac{\sum_{\mathrm{i}=1}^{\mathrm{n}}(\mathrm{Oi}-\mathrm{Pi})^{2}}{\mathrm{n}}} \\
& \operatorname{MAE}=\frac{1}{\mathrm{n}} \sum_{\mathrm{i}=1}^{\mathrm{n}}|\mathrm{Oi}-\mathrm{Pi}| \\
& \mathrm{CRM}=\frac{\sum_{\mathrm{i}=1}^{\mathrm{n}} \mathrm{Pi}-\sum_{\mathrm{i}=1}^{\mathrm{n}} \mathrm{Oi}}{\sum_{\mathrm{i}=1}^{\mathrm{n}} \mathrm{Oi}}
\end{aligned}
$$

Where, Oi is observed WTD above drain on $i^{\text {th }}$ day, $\bar{O}$ is arithmetic mean of observed daily WTD above drain, $\mathrm{Pi}$ is predicted WTD above drain on $\mathrm{i}^{\text {th }}$ day, $\overline{\mathrm{P}}$ is arithmetic mean of predicted daily WTD above drain and $\mathrm{n}$ is number of observations.

\section{RESULTS AND DISCUSSION}

Calibration of DRAINMOD 6.1 model for prediction of WTDs and drain discharges: The WTD and drain discharge data of three months period from SSDS with drain spacing (DS) of $40 \mathrm{~m}$ and drain depth (DD) of $1.0 \mathrm{~m}$ were recorded for calibration of DRAINMOD model. The results on input parameters i.e., data on daily rainfall+irrigation, ETc, layer wise $\mathrm{K}_{\text {sat }}$ of soil, soil moisture capacities at various pressure heads, WTD versus GreenAmpt infiltration parameters, WTD versus downward and upward fluxes, crop data, drainage design system parameters required for simulation of WTD are given below;

\section{DRAINMOD input parameters}

Climatic parameters: The climatic parameters

\begin{tabular}{|c|c|}
\hline Calibration parameter(s) & Source(s) \\
\hline $\begin{array}{l}\text { Lateral } \mathrm{K}_{\text {sat }} \text {, maximum soil surface storage depth, crop root } \\
\text { depth }\end{array}$ & $\begin{array}{l}\text { Zhao et al. (2000), Malota and Senzanje } \\
\text { (2015), Skaggs et al. (2012) }\end{array}$ \\
\hline Monthly ET factors & Jin and Sands (2003), Skaggs et al., (2012) \\
\hline $\begin{array}{l}\text { Drainage coefficient, moisture content of soil at saturation, } \\
\text { residual soil water content, lateral saturated hydraulic con- } \\
\text { ductivity of soil layers }\end{array}$ & $\begin{array}{l}\text { Haan and Skaggs (2003), Singh et al. (2006), } \\
\text { Skaggs et al. (2012) }\end{array}$ \\
\hline Vertical $\mathrm{K}_{\text {sat }}$ of the bottom soil layers & Wang et al. (2006), Skaggs et al. (2012) \\
\hline
\end{tabular}
such as daily Tmax, Tmin, RHmax, RHmin, sunshine hours, wind velocity, Ep and rainfall record-

Table 1. Calibration parameters for DRAINMOD based on literature. 
Table 2. WTDs versus Green-Ampt infiltration parameters used for calibration of model.

\begin{tabular}{llll}
\hline Sr. No. & WTD $\mathbf{( c m )}$ & $\mathbf{A}\left(\mathbf{c m}^{\mathbf{2}} \mathbf{h r} \mathbf{-}^{-1}\right)$ & $\mathbf{B}\left(\mathbf{c m} \mathbf{~ h r} \mathbf{-}^{-1}\right)$ \\
\hline 1 & 0 & 0.00 & 0.42 \\
2 & 10 & 0.18 & 0.42 \\
3 & 20 & 0.35 & 0.42 \\
4 & 50 & 0.67 & 0.42 \\
5 & 100 & 1.00 & 0.42 \\
6 & 200 & 1.53 & 0.50 \\
7 & 250 & 1.68 & 0.50 \\
8 & 500 & 2.09 & 0.50 \\
9 & 1000 & 2.96 & 0.50 \\
\hline
\end{tabular}

Table 3. WTDs versus downward and upward fluxes used for calibration of model.

\begin{tabular}{llcc}
\hline Sr. No. & $\begin{array}{l}\text { WTD } \\
\text { (cm) }\end{array}$ & $\begin{array}{c}\text { Downward } \\
\text { flux }(\mathbf{c m})\end{array}$ & $\begin{array}{c}\text { Upward flux } \\
\left(\mathbf{c m ~} \mathbf{~ h r}^{-1} \mathbf{)}\right.\end{array}$ \\
\hline 1 & 0 & 0.000 & 1.000 \\
2 & 10 & 0.431 & 0.980 \\
3 & 20 & 0.862 & 0.950 \\
4 & 30 & 1.293 & 0.630 \\
5 & 40 & 1.724 & 0.463 \\
6 & 50 & 2.155 & 0.265 \\
7 & 60 & 2.586 & 0.168 \\
8 & 80 & 3.448 & 0.082 \\
9 & 100 & 4.310 & 0.047 \\
10 & 120 & 5.172 & 0.030 \\
11 & 140 & 6.034 & 0.022 \\
12 & 160 & 6.896 & 0.009 \\
13 & 180 & 7.758 & 0.006 \\
14 & 200 & 8.620 & 0.005 \\
15 & 220 & 9.482 & 0.004 \\
16 & 240 & 10.344 & 0.003 \\
17 & 250 & 10.775 & 0.003 \\
18 & 400 & 17.240 & 0.001 \\
19 & 600 & 25.860 & 0.000 \\
20 & 800 & 34.480 & 0.000 \\
21 & 1000 & 100.000 & 0.000 \\
\hline
\end{tabular}

ed daily from the weather station observatory installed at Agricultural Research Station, Kasabe Digraj, Sangli during the period of experimentation from $1^{\text {st }}$ August, 2012 to $29^{\text {th }}$ December, 2013.
DRAINMOD model requires input files on potential evapotranspiration (PET), rainfall and monthly PET factors. However, we calculated ETo, ETc and rainfall+ irrigation as the site is under sugarcane crop. Hence, the monthly PET factors were selected as 1.0 during calibration of model. Further, the data files prepared in the Microsoft Excel spreadsheet on ETc and rainfall+irrigation were then converted to the DRAINMOD model data input format using the DRAINMOD model weather data utility program.

\section{Soil parameters}

Saturated hydraulic conductivity of soil: The saturated hydraulic conductivity $\left(\mathrm{K}_{\text {sat }}\right)$ values of soil at $0-130 \mathrm{~cm}, 130-250 \mathrm{~cm}, 250-300 \mathrm{~cm}$ and $300-370 \mathrm{~cm}^{-1 e p t h}$ were $0.42 \mathrm{~cm} \mathrm{hr}^{-1}, 0.48 \mathrm{~cm} \mathrm{hr}^{-1}$, $0.58 \mathrm{~cm} \mathrm{hr}^{-1}$ and $0.64 \mathrm{~cm} \mathrm{hr}^{-1}$, respectively. The $\mathrm{K}_{\mathrm{sat}}$ at $0-30 \mathrm{~cm}$ soil depth were taken as $1.65 \mathrm{~cm}$ $\mathrm{hr}^{-1}$ while calibrating the model.

Soil moisture capacities: The soil moisture capacities at various pressure heads of $0,10,20$, $50,100,200,250,500,1000,2000,5000,10000$ and $15000 \mathrm{~cm}$ were $0.5,0.487,0.475,0.452$, $0.428,0.403,0.394,0.368,0.344,0.320,0.291$, 0.271 and 0.208 respectively. These values were used as inputs for calibration of DRAINMOD 6.1 model.

WTDs versus Green-Ampt infiltration parameters: The WTD versus Green-Ampt infiltration parameters (A and $B$ ) are given in Table 2.

WTDs versus downward and upward fluxes: The results on WTD versus downward and upward fluxes are mentioned in Table 3.

Crop parameters: The model inputs required on growth of effective roots of sugarcane versus days after its planting are reported in Table 4.

Drainage design system parameters: The inputs on drainage design system parameters were taken from field experiment and the data required on it as an input for calibration of model is given in Table 5 .

Table 4. Effective root depth (cm) days after planting of sugarcane.

\begin{tabular}{llccc}
\hline Sr. No. & Months and Year & Days after planting & Kc & Effective root depth \\
\hline 1 & August, 2012 & 1 & 0.400 & 3.00 \\
2 & September, 2012 & 30 & 0.420 & 4.17 \\
3 & October, 2012 & 60 & 0.630 & 16.45 \\
4 & November, 2012 & 90 & 0.990 & 37.50 \\
5 & December, 2012 & 120 & 1.250 & 52.70 \\
6 & January, 2013 & 150 & 1.310 & 56.20 \\
7 & February, 2013 & 180 & 1.350 & 58.54 \\
8 & March, 2013 & 210 & 1.370 & 59.71 \\
9 & April, 2013 & 240 & 1.375 & 60.00 \\
10 & May, 2013 & 270 & 1.351 & 58.60 \\
11 & June, 2013 & 300 & 1.310 & 56.20 \\
12 & July, 2013 & 330 & 1.265 & 53.57 \\
13 & August, 2013 & 360 & 1.175 & 48.31 \\
14 & September, 2013 & 390 & 1.070 & 42.17 \\
15 & October, 2013 & 420 & 0.955 & 35.45 \\
16 & November, 2013 & 450 & 0.840 & 28.73 \\
17 & December, 2013 & 480 & 0.750 & 23.47 \\
\hline \hline
\end{tabular}


Table 5. Drainage design system parameters used for calibration of model.

\begin{tabular}{lll}
\hline Sr. No. & Drainage design system parameters & Parameter value \\
\hline 1 & Depth of drain from soil surface & $100 \mathrm{~cm}$ \\
2 & Distance between two drains & $4000 \mathrm{~cm}$ \\
3 & Effective radius of drains & $0.36 \mathrm{~cm}$ \\
4 & Depth of impermeable layer from soil surface & $1800 \mathrm{~cm}$ \\
5 & Equivalent depth from drain to permeable layer & $192.37 \mathrm{~cm}$ \\
6 & Drainage coefficient & $0.5 \mathrm{~cm} \mathrm{day}^{-1}$ \\
7 & Initial depth to water table & $154 \mathrm{~cm}$ \\
8 & Maximum surface storage & $7 \mathrm{~cm}$ \\
9 & Kirkham's depth for flow to drains & $7 \mathrm{~cm}$ \\
\hline
\end{tabular}

Table 6. Details of DRAINMOD model calibration parameters.

\begin{tabular}{lll}
\hline Input parameters & Description & Calibrated value \\
\hline Top layer $(0-30 \mathrm{~cm})$ vertical $\mathrm{K}_{\text {sat }}$ & Set at equal to lateral $\mathrm{K}_{\text {sat }}$ & $0.396 \mathrm{~m} \mathrm{day}^{-1}$ \\
Bottom layer $(30-130 \mathrm{~cm})$ vertical $\mathrm{K}_{\text {sat }}$ & Set equal to lateral $\mathrm{K}_{\text {sat }}$ & $0.1008 \mathrm{~m}_{\text {day }}{ }^{-1}$ \\
Bottom layer $(130-1000 \mathrm{~cm})$ vertical $\mathrm{K}_{\text {sat }}$ & Set at $15 \%$ less than lateral $\mathrm{K}_{\text {sat }}$ & $0.12 \mathrm{~m} \mathrm{day}^{-1}$ \\
Maximum soil surface storage depth & Set 14 times the default $0.5 \mathrm{~cm}$ depth & $7.0 \mathrm{~cm}$ \\
\hline
\end{tabular}

Observed WTDs and drain discharges: These observed daily WTDs and corresponding drain discharges were used for calibration and statistical evaluation of the DRAINMOD model.

DRAINMOD model calibration: The DRAINMOD model was calibrated for the three months period i.e., $1^{\text {st }}$ October, 2012 to $31^{\text {st }}$, December 2012. The data on DS of $40 \mathrm{~m}$ and DD of $1.0 \mathrm{~m}$ were used for calibration of DRAINMOD model. The maximum soil surface storage was set at $7 \mathrm{~cm}$ (Skaggs, 2012 reported the expected range of surface water storage as 0.25 to $10 \mathrm{~cm}$ ). The higher value of soil surface storage was set for model calibration because higher irrigation depth (>100 mm) was applied per irrigation through furRAINFALL OR ET

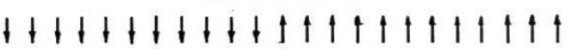

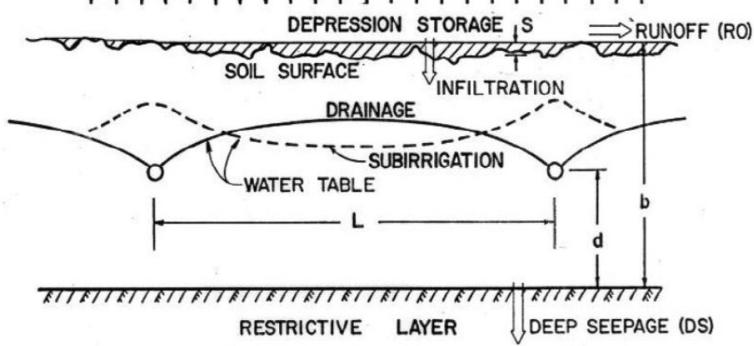

Fig. 1. Schematic of hydrologic processes simulated by DRAINMOD with subsurface drains $\{$ (Skaggs (1985). DRAINMOD: Reference Report)\}.

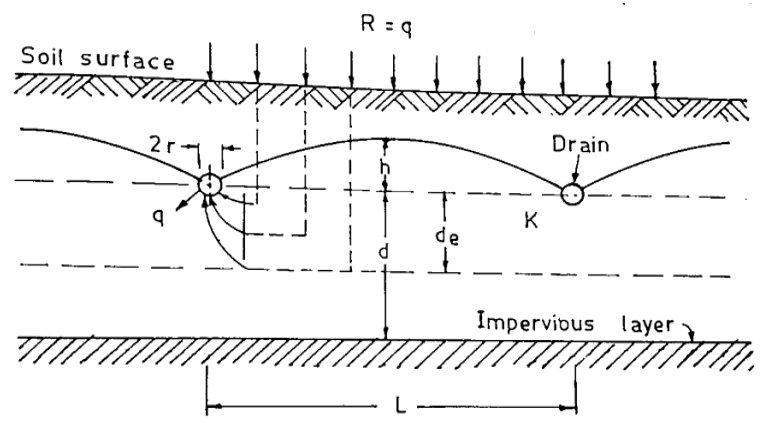

Fig. 2. Subsurface drainage design parameters used in DRAINMOD for Dist. Sangli (Maharashtra), India. row irrigation method. Malota and Senzanje (2015) also set soil surface storage of $2 \mathrm{~cm}$ under sprinkler irrigation system for a 32 ha sugarcane field in Pongola, South Africa. Details of the input parameters that were adjusted during the DRAINMOD model calibration are given in Table 6 .

DRAINMOD model performance: The results of time series of observed and simulated WTDs and drain discharge hydrographs during the calibration period are depicted in Figures 3 and 4, respectively. It is observed from Figure 3 that both observed and simulated WTDs showed a fluctuating trend as expected of arid and semi-arid climatic conditions. It is further observed that this fluctuation of WTD continued, even on non rainy and non irriga-

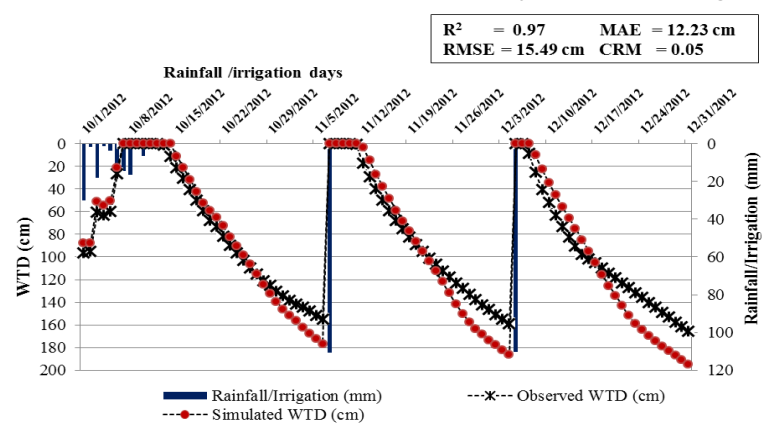

Fig. 3. Observed and simulated WTD fluctuations through DRAINMOD model for Dist. Sangli (Maharashtra), India.

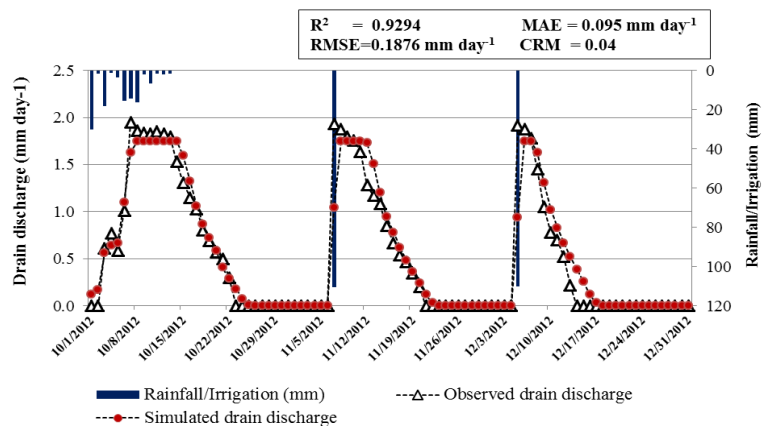

Fig. 4. Observed and simulated drainage discharge hydrograph at Dist. Sangli (Maharashtra), India. 
tion days. The continual WTD or drain discharge fluctuation during the zero recharge days depicts the presence of unsteady state WTD and drain discharge (Skaggs, 1980, Gupta and Yadav, 1993). The unsteady state WTD and drain discharge are not a strange phenomenon in arid and semi-arid climates (FAO, 2007). It is also seen in Figure 3 that peak WTDs coincided with peak rainfall/irrigation days, indicating that the WT was indeed reacting to the recharge through rainfall and irrigation. In addition, model predicted the WTDs very closely with the observed WTDs during frequent rainy days and following the rainy days.

It was further observed from Figure 3 that the model predicted better WTDs up to the DD (100 $\mathrm{cm})$ than below the DD (>100 cm). This might be due to the fact that the DRAINMOD model was developed for humid regions (shallow WTDs) and hence, it predicted better WTDs under shallow WT situations. The shallow WTDs were arised in clay soils due to occurrence of heavy rainfall or excess application of irrigation water through furrow irrigation method and its low drainable porosity and saturated hydraulic conductivity of soil. Further, there may be the existence of inherent water table conditions during rainy days and even in winter season due to possibility of lateral seepage of ground water from the surrounding waterlogged area. This might be responsible for under recording of WTDs below the drain than predicted WTDs below drain. In addition, the results showed that the model predicted WTDs reasonably well, with a very strong $R^{2}$ value of 0.97 , small MAE of 12.23 $\mathrm{cm}$ and RMSE of $15.49 \mathrm{~cm}$. Skaggs et al. (2012) reported that when MAE and RMSE is < $10 \%, 10$ $-15 \%$ and $15-20 \%$ indicates that the simulation performance of model as excellent, good and acceptable, respectively for successful simulation of WTDs with DRAINMOD model. A CRM of 0.05 indicates that the model has a general tendency of over estimating WTDs. Gupta et al. (1993) evaluated DRAINMODunder semi-arid climatic conditions of Kota, India under the RAJAD research project and found good agreement between the measured data and the predicted WTD values with MAE ranged from 14 to $24 \mathrm{~cm}$ and RMSE ranged from 15 to $30 \mathrm{~cm}$ for the four test plots. Skaggs (1982) used field observed input data and predicted WTD of 12 out of 17 sites within 10-15 $\mathrm{cm}$ errors with little or no model calibration. Malota and Senzanje (2015) also evaluated DRAINMOD model successfully with little calibration for irrigated csugarcane field in Pongola, South Africa. Ebrahimian et al. (2010) reported that the MAE, RMSE and $R^{2}$ as $15.6 \mathrm{~cm}, 18.1 \mathrm{~cm}$ and 0.42 , respectively for prediction of WTDs with DRAINMOD in North of Iran. Samipour et al. (2010) also reported the $R^{2}$ and RMSE of 0.95 and $18.1 \mathrm{~cm}$, respectively for prediction of WTDs with DRAIN-

\section{MOD in Iran.}

Results of the time series observed and simulated drain discharge hydrographs during the calibration period are given in Figure 4. It is observed from Figure 4 that both observed and simulated drain discharge hydrographs showed a fluctuating trend, depicting the presence of unsteady state drain discharge behavior. It is further observed from Figure 4 that a very good correlation between the observed and simulated drainage discharge hydrographs can visually be deduced. Statistically, observed and simulated drain discharge hydrographs showed a good agreement with a high $\mathrm{R}^{2}$ of 0.93 , small MAE of $0.095 \mathrm{~mm}^{\text {day }}{ }^{-1}$ and RMSE of $0.1876 \mathrm{~mm}$ day $^{-1}$. The CRM of 0.04 indicates that the model has a general tendency of over estimating drain discharges. Ebrahimian et al. (2010) reported that the MAE, RMSE and $R^{2}$ of $0.27 \mathrm{~mm}$ day $^{-1}, 0.32 \mathrm{~mm}$ day $^{-1}$ and 0.71 , respectively for prediction of drain discharges with DRAINMOD in North of Iran.

The comparison of the $R^{2}$ values between pairs of observed and simulated WTDs in Figure 1 and drain discharges in Figure 2 clearly showed that the model performed better in predicting WTDs $\left(R^{2}=0.97\right)$ than drain discharges $\left(R^{2}=0.93\right)$. In general, a good agreement was found between the observed and the predicted values of WTDs and drain discharges.

\section{Conclusion}

Based on field evaluation under SSDS with $40 \mathrm{~m}$ drain spacing and $1.0 \mathrm{~m}$ drain depth at Sangli district of Maharashtra, India, DRAINMOD model was calibrated successfully and this calibrated DRAINMOD model can be used for simulation of water table depths and drain discharges under SSDS in irrigated Vertisols and in turn for computing the design parameters of subsurface drainage system.

\section{REFERENCES}

1. Borin, M., Morari, F., Bonaiti, G., Paasch, M. and Skaggs, R.W. (2000). Analysis of DRAINMOD performances with different detail of soil input data in the Veneto region of Italy. Agricultural Water Management, 42(3): 259-272.

2. Dayyani, S., Madramootoo, C.A., Prasher, S.O., Madani A. and Enright, P. (2010). Modeling water table depths, drain outflow, and Nitrogen Losses in a cold climate using DRAINMOD 5.1. Transactions of the ASAE, 53(2): 385-395.

3. Ebrahimian, H., Ojaghlou, H., Liaghat, A., Parsinejad, M., Nazari, B. and Noory, H. (2010). Comparison of DRAINMOD and Artificial Neural Network for predicting water table depth and drain discharge in a subsurface drainage system. Paper presented at $9^{\text {th }}$ International Drainage Symposium held jointly with CIGR and CSBE/SCGAB Proceedings, 13-16 June 2010 IDS-CSBE-100087. (doi:10.13031/2013.32117).

4. FAO. (2007). Guidelines and computer programs for the planning and design of land drainage. Food and 
Agricultural Organization of the United Nations. Irrigation and drainage paper No.62. Rome, Italy.

5. FAO (2015). AQUASTAT website. Food and Agricultural Organizations of the United Nations. Website accessed on (24/12/2016). http:// www.fao.org>water>cropinfo_sugarcane.

6. Green, W.H. and Ampt, G. (1911). Studies of soil physics, part I. the flow of air and water through soils. Journal of Agricultural Sciences, 4: 1.

7. Gupta, G.P., Prasher, S.O., Chieng S.T. and Mathur, I.N. (1993). Application of DRAINMOD under semiarid conditions. Agricultural Water Management, 24 (1): 63-80.

8. Gupta, R. and Yadav, R.L. (1993). Ground water contribution to evapotranspiration of sugarcane during summer. Cooperative Sugar, 25: 113-115.

9. Haan, P.K. and Skaggs, R.W. (2003). Effect of parameter uncertainty on DRAINMOD predictions: Hydrology and yield. Transactions of ASAE, 46(4): 1061 $-1067$.

10.Hamdi, M.R., Aldabagh, A.S. and Gazhal, E.M. (2006). Optimal drainage design under Iraqi conditions using DRAINMOD. Al-Rafidain Engineering, 14 (2): 88-99.

11.Hassanpour, B., Parsinejad, M., Yazdani, M.R., Dalivand, F.S. and Kossari, H. (2011). Evaluation of modified DRAINMOD in predicting groundwater table fluctuations and yield of canola in paddy fields under snowy conditions (case study: Rasht Iran). Irrigation and Drainage, 60: 660-667.

12. Hooghoudt, S.B. (1940). General consideration of the problem of field drainage by parallel drains, ditches, watercourses, and channels. Publication No.7 in the series contribution to the knowledge of some physical parameters of the soil (titles translated from Dutch). Bodemkundig Insitituut, Groningen, The Netherlands.

13.Jin, C.X. and Sands, G.R. (2003). The long-term Field-Scale Hydrology of Subsurface Drainage Systems in a Cold Climate. Transactions of the ASAE, 46(4): 1011-1021.

14.Malota, M. and Senzanje, A. (2015). Modelling midspan water table depth and drainage discharge dynamics using DRAINMOD 6.1 in a sugarcane field in Pongola, South Africa. Water South Africa, 41(3): 325-334.

15.Mohammadighavam, S. and Klove, B. (2016). Evaluation of DRAINMOD 6.1 for Hydrological simulations of peat extraction areas in Northern Finland. Journal of Irrigation and Drainage. DOI: 10.1061/ (ASCE) IR.1943-4774.0001086.

16.Murthy, R.S., Bhattacharjee, J.C., Landey, R.J. and Pofali, R.M. (1982). Distribution, characteristics and classification of Vertisols. In: Vertisols and rice soils of the tropics. Twelth International Congress of Soil Science, New Delhi, India, 8-16 February 1982. Indian Society of Soil Science, New Delhi, India. pp. 3-22

17.Neveen, B., Abdel, M. and Alaa Nabil, E.H. (2013). Subsurface drainage impact assessment in Ibshan, Egypt. Journal of Environmental Science and Engineering, B 2: 527-531.
18.Prasher, S., Madani, A., Clemente, R.S., Geng, G.Q. and Bardwaj, A. (1996). Evaluation of two water table management models for Atlantic Canada. Agricultural Water Management, 32(1): 49-69.

19.Rathod, S. D. (2017). Optimization of subsurface drain spacing and depth for sugarcane (Sachharum officinarum L.) under waterlogged Vertisols. Unpublished Ph.D. Thesis, Mahatma Phule Krishi Vidyapeeth, Rahuri, Ahmednagar (M.S.).

20.Samipour F., Rabie, M., Mohammadi, K., Mahdian, M.H. and Naseri, A.A. (2010). Evaluation of two drainage models in South - West Iran. Paper presented in XVII ${ }^{\text {th }}$ World Congress of the International Commission of Agricultural and Biosystems Engineering, Canada, June 13-17.

21.Sanai, G. and Jain, P.K. (2006). Evaluation of DRAINMOD for predicting water table heights in irrigated fields at the Jordan Valley. Agricultural Water Management, 79(2): 137-159.

22.Savva, A. and Frenken, K. (2001). Sprinkler Irrigation Systems Planning, Design, Operation and Maintenance. Food and Agriculture Organization of the United Nations, Sub-Regional Office for East and Southern Africa (SAFR), Harare.

23.Sema Kale. (2011). Estimating effects of drainage design parameters on crop yields under irrigated lands using DRAINMOD. Scientific Research and Essays, 6(14): 2955-2963.

24.Singh, R., Helmers, M.J. and Zhiming, Qi. (2006). Calibration and validation of DRAINMOD to design drainage systems for IOWA's tile landscapes. Agricultural Water Management, 85: 221-232.

25.Skaggs, R.W. (1978). A water management model for shallow water table soils. Technical report No. 134. Water Resources Research Institute of the University of North Carolina, Raleigh, N.C. USA. 178 pp.

26.Skaggs, R.W. (1980). Methods for design and evaluation of drainage-water management systems for soils with high water tables. DRAINMOD reference report. USDA-SCS, South National Technical Center, Fort Worth, Texas. $329 \mathrm{pp}$.

27.Skaggs, R.W. (1985). Drainage modelling in research and design. In: Proceedings of International seminar on land drainage (edited by J. Saavalainen and P. Vakkilainen). Helsinki University of Technology: $153-180$.

28.Skaggs, R.W., Youssef, M.A. and Chescheir, G.M. (2012). DRAINMOD: Model use, calibration, and validation. Transactions of the ASABE, 55(4): 1509 1522. doi:10.13031/2013.42259)@ 2012.

29.Wang, X., Mosley, C.T., Frankenberger, J.R. and Kladivko, E.J. (2006). Subsurface drain flow and crop yield predictions for different drain spacings using DRAINMOD. Agricultural Water Management, 79: 113-136.

30.Yang, X. (2008). Evaluation and application of DRAINMOD in an Australian sugarcane field. Agricultural Water Management, 95(4): 439-446.

31.Zhao, S.L., Gupta, S.C., Huggins, D.R. and Moncrief, J.F. (2000). Predicting subsurface drainage, corn yield, and nitrate-nitrogen losses with DRAINMOD-N. Environmental Quality, 29(3): 817-827. 